\title{
Assessment of the Effectiveness of Ghanaian Micro-Finance Institutions in Promoting Entrepreneurs in Accra Metropolis
}

\author{
Akwasi A. Boateng ${ }^{*}$, Gilbert O. Boateng ${ }^{2}$ \\ 1. School of Business, Cape Coast Polytechnic, P.O.Box AB 50, Cape Coast, Ghana \\ 2. School of Business, Takoradi Polytechnic, P.O.Box 256, Takoradi, Ghana \\ Corresponding e-mail: gillyboateng@yahoo.com
}

\begin{abstract}
Bank of Ghana in 2011 issued Micro-finance Rules and Guidelines with the aim of promoting entrepreneurship activities in micro and small enterprises in Ghana. The study examined the effectiveness of Micro finance Institutions in promoting entrepreneurs in Accra Metropolis in the period 2011 to 2013. A purposive and simple random sampling technique was employed to draw the sample from the population. Personal interviews and structured questionnaires were used to facilitate the acquisition of relevant data which was used for analysis. Descriptive statistics which involves simple percentage and illustrations was purposefully applied in data presentations and analysis. The research revealed that only a few entrepreneurs had accessed loans from Micro Finance Institutions, due to high interest rates, ignorance of the existence of Micro Finance Institutions as well as lack of trust and confidence in the Micro Finance Institutions. It was concluded that Micro Finance Institutions in Accra Metropolis are less effective in promoting entrepreneurs. The researchers recommended that the Bank of Ghana and Ghana Association of Microfinance Companies must ensure transparency and integrity in Micro Finance Institutions operations to increase their outreach. In addition, Ghana Association of Microfinance Companies and its members must enhance public awareness about Micro Finance Institutions operations through various promotional strategies.
\end{abstract}

Keywords: Micro-Finance Institutions, entrepreneurs, micro and small enterprises, Accra Metropolis, GAMC

\section{Introduction}

Micro-finance concept has been in operation for centuries in different parts of the world, for example, "Notable" in Indonesia, "cheetu" in Sri Lanka, "tontines" in Cameroon, "susu" in Ghana and "pasanaku" in Bolivia. It dates back in the 19th century when money lenders were informally carrying out the role of now formal financial institutions. Microfinance has developed as a socio-economic development tool intended to benefit many different customers who are excluded from the formal financial system i.e. low-income earners. A main aim of many micro finance institutions (MFIs) is to provide sustainable micro finance facilities to the poor and low income, self-employed or household-based businesses to facilitate income generation and reduce poverty (Baumann, 2001, 2004).

MFIs provide services targeted at Micro and Small Enterprises (MSEs). MFIs play a significant role in national economies by providing credit facilities to this segment of the market ignored by the formal financial system. In industrialized countries like the United States of America and the United Kingdom, MSEs play an important role in the economy, accounting for an estimated one third of industrial employment and a lower percentage of output. In developing and transitory countries where MSEs dominate economically active organizations, the MSEs' prosperity is considered far more significant than in industrialized countries (Rwigema et al, 1999).

In Ghana, MSEs have played a great role and have been a significant provider of employment. According to Abor et al (2010), MSMEs account for $92 \%$ of all businesses in Ghana and contribute about $70 \%$ of Gross Domestic Product (GDP) of Ghana. Moreover with Ghana having the highest literacy rate in West Africa subregion at $74.1 \%$ (US Department of State and Central Intelligent Agent world fact book: 2012 publication) and with over 7 million of 24.6 million population still living below the poverty line despite Ghana's current lower middle income status (www.ghanaweb.com). Most of these educated people fail to get employment in the formal sector as a result of collapse of Ghana's industrial base due to ineffective management, shrinking of public sector employment opportunities coupled with relatively slow growth of the private sector and thus have employed themselves and other people as entrepreneurs by starting business ventures. It is well-known that the MSEs provide good opportunities for poverty alleviation and reduction in social ills associated with unemployment in the economy. It makes available the raw materials required by the manufacturing sector hence vehicle for industrialization. Its role in the local supply of raw materials has twin positive effects of cost-saving to the manufacturing firms as well as moderation of tendency of balance of payment deficit.

Essentially, microfinance is a way for low-income households and their businesses to gain access to traditional economic resources such as lines of credit (also denoted to as "microcredit") and loans, the sorts of tools that households and fledgling enterprises would need in an economic setting. Though the principle of managing money on a small scale has been in existence for years, the industry of microfinance has only in the last three decades really expanded and provided access to financial and non-financial services for hundreds of millions of 
people who might not otherwise have it. In other words, the micro finance revolution, a recent product of development, ensures the availability of institutional credit and financial inclusion to the poor and vulnerable households, who were so far excluded from the institutional credit system.

Ghana has been characterized by high unemployment levels exceeding 14\% (US Department of State and Central Intelligent Agent world fact book: 2012 publication), the number of well-educated people on the roads is incredible. High unemployment levels have unquestionably contributed to high levels of poverty and poor standards of living in the environment of intensifying globalization. During and after the economic crunch most people have ventured into the informal business sector. However, greater numbers of these individuals who have informal enterprises are lacking funding as a result of failing to access funds from universal banks and other financial institutions. This demand for the MFIs to effectively partake in promoting entrepreneurs by providing the financial and non-financial needs that best suits the entrepreneurs.

The activities of MSEs in Africa (Rogerson, 2001), is of vital significance for the promotion of socio-economic development, job generation and poverty eradication coupled with policy makers and practitioners current interest in empowerment potential of entrepreneurs makes an assessment of the effectiveness of Ghanaian MFIs in promoting entrepreneurs very significant. This is buttressed by United Nations' declaring year 2005 as year of micro credit since the policy makers of UN supported the view that micro finance is an instrument to fight against poverty. According to Nobel Committee, micro finance can help the people to break poverty, which in turn is seen as an important prerequisite to establishing long lasting peace.

The study focuses on MFIs in the Accra Metropolitan Assembly (AMA) of Greater Accra Region of Ghana. An analysis of studies on MFIs in Ghana revealed that few studies have been made in the past to evaluate the effectiveness of MFIs' contribution to development of MSEs with a focus on AMA. The main objective is to evaluate the effectiveness of Ghanaian MFIs in the promotion of entrepreneurs in AMA from 2011 to 2013 ; specifically the study seeks to: (i) ascertain the nature and kinds of credit facilities and other non-credit services offered by Ghanaian MFIs, (ii) evaluate the compliance of Ghana MFIs to microfinance rules and guidelines; and (iii) assess the contribution of Ghanaian MFIs in employment generation.

The remainder of the paper is organized as follows. The next section describes the relevant literature. Next, we discuss the data and methodology used in the study. The results are presented in the following section. The paper closes with some concluding comments.

\section{Literature review}

2.1 Microfinance products and services

The notion of micro finance has for long been misinterpreted as micro-credit (micro loans to household-based entrepreneurs (Okenyebuno, 2007) and these two terms are used interchangeably, although the term micro finance connotes broader activity. This misconception has led to a restrictive focus by some MFIs which have not permitted them to have a comprehensive range of products and services. Morduch (1998), Dunnford et al (1999), Khandker (1998) and Amin et al (1998) share the same view that micro-credit or micro loans though used interchangeably with micro finance, is simply one of the many components that constitute the larger range of micro finance services. Ledgerwood, (1999), Igbinedion et al, (2004) Okenyebuno, (2007), are of the opinion that established micro- finance products and services consist of micro loans, savings, micro-insurance, business management education and money transfers. It also involves the provision of working capital, informal/formal assessment of borrowers and investments, collateral surrogates such as group guarantee or compulsory savings; access to repeated and large loans, streamlined loan disbursement, advice and monitoring techniques.

Also, Baumann (2004) is of the view that micro finance services comprise of both financial and social intermediation including group formation, and training in financial literacy and business management practices. Hulme et al (1997) suggested that MFIs should take cognizance of the varying needs of various segments of the poor customers in their design of financial services. Thus, in planning and implementing micro finance services, there is the need to note that credit has different implications for different sections of the poor and as such could generate additional risk for the very poor. Sebstad et al (2003) added that it is therefore pragmatic for MFIs to diversify their hitherto relatively standardized products and services in line with environmental distinctiveness. Additionally, Rutherford (1999), Quansah et al (2012) Cohen (2002) and Woller (2002) advocate customerfocused services for MFIs as a vital ingredient for effective service delivery and influence on the lives, resources and families of the economically active poor. Smith (2002), Banerjee et al (2009) and Ahmed et al (2001) agree on the need for MFIs to provide all inclusive micro finance products. They opine that MFIs, which they surveyed, have experienced statistically substantial improvement in their performance as a result of amalgamation of financial services with non-financial services being rendered to customers. In recent time, Okenyebuno (2007) has noted that, micro finance delivery instruments (for services rendered in Nigeria, as in other parts of the world) include, but not restricted to, a combination of group - lending, individual lending, dynamic incentives, regular repayment and collateral substitutes. 


\subsection{Outreach of MFIs}

Outreach at glance means the number of customers served. To scale up programs to reach out to a large number of customers with a small amount of resources has proved an elusive target of many microfinance schemes because of monetary and non-monetary constraints. According to Lariviere et al (1998) an emphasis on scale is not always having positive impact because to some extent this effort can be counter-productive to the aim of creating sustainable financial institutions for the poor. According to Cull et al (2007), outreach can be defined to cover the scale, geographical outreach, depth of outreach, quality and breadth of outreach. They further alluded that outreach can be roughly measured by the "volume of annual lending and savings activities (scope), and the population it serves (depth of market penetration)"

Meyer (2002) noted that outreach is a multidimensional idea, meaning that its measurement requires looking into different dimensions. According to Schreiner (2002), outreach is defined as an assessment of the number of under-privileged customers served by MFIs. Based on Meyer et al (2002) framework; outreach needs to be measured through different dimensions. According to MIX (2005), outreach can be evaluated by an annual comparative analysis through measurement of several variables including number of personnel and active borrowers, percentage of customers served below poverty line, average loan balance per borrower, percentage of woman borrowers, number of savers etc. Navajas et al (2000), has identified six main attributes for outreach measurement. These include, breadth, worth to borrowers, cost to borrowers, scope and length. Meyer et al (2002) have used similar indicators in their framework, for measuring MFIs outreach.

According to recent statistics of the Microfinance Information Exchange market database (MIX Market), 198 MFIs in 10 regions of Ghana reported that they have 300,875 active borrowers with a gross loan portfolio of USD224.6 million in 2011. These figures increased significantly in the following few years where 560 MFIs in 10 regions reported that they had 3 million active borrowers with a gross loan portfolio of USD 461 million in 2013. The number of people so far reached by MFIs across the nation and the increase in the gross loan portfolio in these institutions clearly indicate how large the microfinance industry is and how fast it is growing. In fact the world-wide demand for microfinance services is considered to be much higher than what is currently served. Although MFIs are currently serving hundreds of millions of people, estimates for the actual demand ranges from around 1 billion to 2.5 billion people, indicating that a very substantial share of the market still remains unexploited.

\subsection{MFIs contribution to employment generation}

Khan et al (2007), Robinson (2001), Otero (1999) and Wehrell et al. (2002) have all recounted successful results of microfinance programs in terms of creating employment opportunities and improving the earnings as well as economic well-being of hundreds of millions of poor and vulnerable households around the world. However, as unemployment and underemployment has become a major concern in today's world after the severe global economic crunch, microfinance became a treasured alternative again, particularly in targeting the needs of the most vulnerable households and their businesses. While MFIs know the employment status of the direct customers, they know much less, if anything, of the increases or decreases in household labour, contract labour, trainees or non-household labour.

GHAMFIN (2006) reveal in their study on microfinance programs in Ghana that the impact of the financial and non-financial service provision by MFIs at the enterprise level is positive in many respects: wage earning employees becoming micro entrepreneurs, increased asset creation and savings, enterprise size and higher employment generation, both the quantitative and qualitative assessment show that the provision of loans by MFIs has assisted customers to keep them going even in the most challenging periods, as well as contribute to providing continued employment to customers and their families, and to increase the number of employees in their businesses, either on temporary or permanent basis. Again, Kushoka (2013) examining the "contribution of MFIs on entrepreneurship development in Tanzania" reveals that there is an increase in the number of employees and amount of working capital of entrepreneurs after using the services of MFIs.

According to the Ghana Poverty Reduction Strategy (GRPS II) of 2010, a large number of Ghanaians derive their livelihood from MSEs. Therefore, development of this sector represents a significant means of generating employment, promoting socio-economic development, and eradicating poverty in the long run. However, in spite of the significance of this sector, experience shows that provision and delivery of credit and other financial services to the sector by formal credit institutions, such as MFIs has been below expectation. This means that it is challenging for the poor households to climb out of poverty due to lack of funds for their productive activities. Therefore, new, well-though-out, innovative and pro-poor methods of funding low income families and MSEs based on sound operating philosophies need to be established.

Idowu (2010) observes that MFIs aim to advance the socio-economic well-being of women, particularly those in the rural communities through the provision of credit support, new skills and technologies acquisition, reproductive health care service, adult literacy and girl child education. In addition, they aim at building community capacities for wealth creation among enterprising poor household and to promote sustainable livelihood by strengthening rural responsive banking procedure as well as eradicate poverty through the 
provision of microcredit and skill acquisition development for revenue generation. In other words, it contributes to improvement in household economic welfare and enterprise stability or growth and micro finance is empowering women, thus bringing gender equality.

\section{Methodology}

Both primary and secondary data were collected to assess the effectiveness of Ghanaian MFIs in promoting entrepreneurs in Accra metropolis. Primary data was collected by administering questionnaires, and secondary data obtained from periodicals, reports, newspapers, monographs, published books, journals, internet etc. The population of the study consist of all tier two (2) MFIs licensed by Bank of Ghana (BOG) as well as being members of Ghana Association of Microfinance Companies (GAMC) and MSEs operating in Accra Metropolitan Assembly (AMA).

The study adopted purposive and simple random sampling techniques to draw the sample from the population. The MFIs and MSEs were randomly drawn from four (4) sub-metropolitan areas; namely, Abossey Okai, Okaikoi South, Ablekuma North and Osu Klottey. These sub-metros were chosen because they constitute the main commercial hub in the metros hence have larger number of MSEs and MFIs in the assembly. The interview method was also used to probe into some fundamental issues raised on the questionnaire. A total of 68 entrepreneurs were interviewed face to face based on the retrieved questionnaires by the researchers. The interviews lasted between 25 and 30 minutes.

A total of 120 questionnaires were distributed to MFIs and MSEs operating in the study area. The questionnaires were distributed in the following manner: a total of eighty (80) went to MSEs (i.e. chop bars, seamstresses, hairdressers, street hawkers, lotto kiosk operators, licensed drug stores, mobile phone shops, photocopying and printing shops, stationery shops, computer shops, internet cafes, second hand-clothing shops, small grocery shops, driving schools, artisans, electrical gadgets shops, and petty traders) in the study area. The questionnaires were apportioned in this manner: twenty (20) questionnaires for Abossey Okai, twenty five (25) questionnaires for Okaikoi South, fifteen (15) questionnaires for Ablekuma North and twenty (20) questionnaires for Osu Klottey. A total of forty (40) questionnaires were administered to MFIs in the study area in the following manner: eight (8) questionnaires for Abossey Okai, eleven (11) questionnaires for OkaiKoi South, seven (7) questionnaires for Ablekuma North and fourteen (14) questionnaires for Osu Klottey.

The return rate of completed questionnaires was 65 percent as we were able to get back 78 out of 120 questionnaires given to our respondents. Thus, only 78 questionnaires were used for final analysis in this study. However, 78 consisted of 10 MFIs and 68 MSEs (18 from Abossey Okai, 25 from Okaikoi South, 15 from Ablekuma North and 20 from Osu Klottey). In an effort of making the presentation of information clearer and easy to comprehend, tables, frequency counts, and percentages were used.

\section{Data presentation and analysis}

Micaid Microfinance offers business loans, civil servants loans, susu loans, overdraft loans and other financing. The interest rate is $6 \%$ per month for all these loans. It charges an interest rate of $4 \%$ per month for its loans. Legacy Capital Microfinance offers consumer loans, micro projects loans and order financing, all of which are short term loans carrying an interest rate of $7 \%$ per month. Apart from provision of loans it also provides financial education.

Christian Community Microfinance offers business loans which mainly target christians under the scheme known as Believers Funds (BFs) though it comprises both christians and non-christians who are in business. It also offer salary based loans for low income earners and security based loans for consumption for those who neither have a business nor employed. All these loans carry an interest rate of 4\% per month and they are payable in six (6) months. Apart from loans it provides entrepreneurship training services such as capacity building and economic empowerment for women as well as group mobilisation, HIV/AIDS awareness.

Reob-Fekams Microfinance offers import clearing loan, order financing, working capital finance, salary loans and personal loans, all of which carries an interest rate of $8 \%$ per month. CIG Microfinance provides business loans, personal loans with a minimum amount of GHф500 attracting an interest rate of 5.5\% per month. In addition they provide pre-loan financial education.

AG Microfinance provides funeral loans, micro-leasing loans, salary loans and vehicle hire purchase finance carrying an interest rate of $4 \%$ per month on a reducing balance basis. Nationwide Microfinance offers salary based loans, import emergency finance and bridging finance carrying an interest rate of 5\% per month. Noble Microfinance provides funeral emergency loans, clearing emergency loans, and vehicle loans carrying an interest rate of $6 \%$ per month on flat rate basis. In addition to loans, investments, it also provides training aimed at equipping businessmen and businesswomen with business skills.

Multimoney Microfinance provides short term loans mainly for working capital and consumer loans with a maximum amount of $\mathrm{GH} \varnothing 15,000$ and a minimum of $\mathrm{GH} \notin 500$ carrying an interest rate of $6 \%$ to $8 \%$ per month on flat rate basis. Apart from loans it also provides business development services such as training of MSEs in 
business and financial management. Goldman Microfinance provides personal loans, import clearing loans, salary loans, business loans and vehicle finance attracting an interest rate of 5\%-10\% per month on reducing balance basis.

4.1 Outreach of GAMCs

From the study two (2) MFIs were found to have only one (1) branch which is the Accra branch and these are Micaid Microfinance, and Multimoney Microfinance. CIG Microfinance has got 9 branches countrywide and Noble Microfinance has 19 branches countrywide located in Bodi-Sefwi in Western Region, Accra-Central in Greater Accra Region, Techiman and Dormaa in Brong Ahafo region and 15 in Ashanti Region. Legacy Microfinance has 5 branches countrywide located in Kasoa in Central Region, Konongo in Ashanti Region, and Osu, Abaka-Lapaz, and Nungua all in Greater Accra Region. Nationwide Microfinance has got 4 branches countrywide located in Swedru in Central Region, Tema, Ashaiman and Abaka-Lapaz in the Greater Accra Region. AG Microfinance has got 3 branches countrywide located in Abaka-Lapaz and Tema in the Greater Accra Region and Kumasi in the Ashanti Region respectively. Christian Mothers Microfinance has got 18 branches nationwide.

Reob-Fekams Microfinance has got 3 branches located in Abaka-Lapaz, Asylum Down and Circle all in the AMA of Greater Accra Region. Finally Goldman Microfinance has got 6 branches located in Tarkwa and Takoradi in the Western Region and four (4) in Greater Accra Region.

Table 1: Outreach of MFIs in terms of number of branches

\begin{tabular}{lc}
\hline \multicolumn{1}{c}{ Microfinance Institutions } & Number of Branches \\
\hline Goldman Capital Microfinance & 6 \\
Legacy Capital Microfinance & 5 \\
Christian Community Microfinance & 18 \\
CIG Microfinance & 9 \\
AG Microfinance & 3 \\
Nationwide Microfinance & 4 \\
Reob-Fekams Microfinance & 3 \\
Micaid Microfinance & 3 \\
Multimoney Microfinance & 1 \\
Noble Microfinance & 1 \\
\hline Source: Field Survey, January 2014. The Table shows number of MFIs and their branchescountrywide.
\end{tabular}

Source: Field Survey, January 2014. The Table shows number of MFIs and their branches countrywide.

The researchers were much concerned with the geographical coverage of MFIs in as far as outreach is concerned. It was discovered from the study that $90 \%$ of the MFIs which were under investigation only have branches in the urban and semi-urban areas and just $10 \%$ have some branches in the rural areas. These results also concur with the findings of Peprah et al, (2010) that only a few MFIs are found in the rural communities due to low population size, population density and economic activities in the rural communities and other challenges of rural financial inclusion. Thus, promoters and investors of MFIs locate their institutions in areas where they will have the ability to recoup their investments quickly. Ghanaian MFIs have been poor in terms of outreach as compared to MFIs in countries such as Kenya, Uganda etc as a result of small capital base and telescoped portfolios.

The study showed that Ghanaian MFIs are contributing to employment generation through employing people in their businesses. Employment generation as a result of MSEs promotion is very low. This is evidenced by the distribution of the number of MSEs who access loans from the MFIs versus those who have never accessed any loan from them. Out of 68 entrepreneurs in AMA only $13(19.12 \%)$ entrepreneurs were found to have accessed loans from MFIs and the information is presented in Table 2 below:

Table 2: Entrepreneurs access to MFIs loans

$$
\begin{array}{lll}
\text { Response } & \text { Frequency } & \text { Percentage (\%) }
\end{array}
$$

\begin{tabular}{lcc}
\hline Never Access MFIs Loan & 55 & 80.88 \\
Access MFIs Loan & 13 & 19.12 \\
Total & 68 & 100 \\
\hline Source: Field Survey, January 2014. This table shows frequency distribution of entrepreneurs that have and \\
have not accessed micro loans from MFIs. \\
Some of the reasons for entrepreneurs failure to access loans from MFIs as given by the respondents included
\end{tabular}


relatively high interest rates that are charged on the MFI loans which makes their funds too costly coupled with what they saw to be tough repayment schedules and enforcement methods. This is evidenced by per annum interest rate charges of MFIs and some selected Universal Banks in Ghana as presented in Table 3 below. The cost of funds tend to be too high and the repayment periods are very short thus exerting a burden on entrepreneurs to the extent that they become trapped in debts spiral as they would borrow from friends, family, other MFIs in order to pay the MFIs to avoid potentially harmful penalties.

Table 3: Interest rate charges per annum of MFIs and Selected Universal Banks

\begin{tabular}{lclc}
\hline MFIs & Interest Rate & Selected Universal Banks & Interest Rate \\
\hline Goldman Capital Microfinance & $90 \%$ & Barclay Bank Ghana Limited & $31.27 \%$ \\
Legacy Capital Microfinance & $84 \%$ & HFC Bank & $27.63 \%$ \\
Christian Community Microfinance & $48 \%$ & Fidelity Bank & $29 \%$ \\
CIG Microfinance & $66 \%$ & National Investment Bank & $26.07 \%$ \\
AG Microfinance & $48 \%$ & Agricultural Development Bank & $26.22 \%$ \\
Nationwide Microfinance & $48 \%$ & Standard Chartered Bank & $24.18 \&$ \\
Reob-Fekams Microfinance & $96 \%$ & Energy Bank & $29.74 \%$ \\
Micaid Microfinance & $72 \%$ & Bank of Africa & $38.02 \%$ \\
Multimoney Microfinance & $60 \%$ & CAL Limited & $26.49 \%$ \\
Noble Microfinance & $60 \%$ & Societe Generale-SSB & $26.68 \%$
\end{tabular}

Source: Field Survey, January 2014. This shows interest rates charges per annum of MFIs and selected universal banks in Ghana. It confirms that interest charges of MFIs are relatively high

Some respondents who have tried to access loans from MFIs could either not get the loans or were not given the full amount primarily due to paucity of loanable funds which will make them fail to meet the financial needs of the entrepreneurs.

Some respondents said that they are not even willing to deal with the MFIs because they are dishonest, fraudsters and they can close any time. This concurs with reported incidents of MFIs closing and taking with them depositors' savings in many areas of the country (business.myjoyonline.com). Some entrepreneurs are not even aware of the existence of MFIs; they do not even know what they are and what are they responsible for. This is a sign of lack of public awareness, under such circumstances some entrepreneurs fail to access funds because they are ignorant of MFIs and their function.

GAMCs' contribution towards employment generation have been very pitiable as compared to MFIs in other countries due to the liquidity challenges that the economy is currently facing as well as very low economic growth that Ghana is experiencing.

4.2 Recommendations

The interest rates charged on MFI loans should not be relatively high to enable viable repayment of loans. Transparency should also be ensured in the operations of the GAMCs as well as elucidation and standardization of interest rates so as to ensure that no MFIs are taking undue advantage of innocent customers by actually making a lot of money out of them in the form of relatively high interest rates.

From the research it shows that a number of people are not even aware of the MFIs and their operations and even those who are aware of them do not even have confidence and trust in them. The researchers therefore recommend GAMCs and its members to massively invest in promotional schemes to increase public awareness and to instil confidence and trust in the minds of the public, as well as to educate the public about the MFIs and their operations.

Most of the businesses that access loans from the MFIs find themselves plummeting in debt. To overcome this challenge GAMCs are recommended to train their customers so as to improve their capacity in successfully setting up, managing and developing their businesses and to increase their entrepreneurial competence as well as to encourage them to be accountable, to plan, record and design their businesses.

GAMCs are also recommended to be involved in the appraisal of borrowers and their investments as well as advising them on issues pertaining to their businesses. Investing in monitoring the performance of their customers can also be a significant basis for building viable repayment capacity as well as development capacity. Finally GAMCs' recommended approach to business must be to foster economic growth and development by increasing productivity and employment opportunities.

\section{Conclusion and the way forward}

This paper set out to assess the effectiveness of Ghanaian MFIs in the promotion of entrepreneurs in AMA from 2011 to 2013. The study explored both theoretical and empirical evidence as bases for the research. It made use 
of questionnaires and interviews for collecting data from a sample of MSEs and MFIs in AMA. Tables were used to describe the responses for better understanding. The results showed that MFIs' contribution to promotion of MSEs is low, interest rates charges are relatively high, MFIs have weak capital base and lack of public awareness. Time and financial constraints did not allow for larger sample size and limited the scope of the research to only the Accra Metropolitan Assembly with a sample size of 120 MSEs and MFIs. In future, different methods of research could be used for study of the same topic or other related aspects of the topic. Specifically future research should focus on the role of microfinance on rural microenterprise development in rural Ghana.

\section{REFERENCES}

Abor, J. \& Quartey, P., (2010). "Issues in SME Development in Ghana and South Africa", International Research Journal of Finance and Economics ISSN 1450-2887 Issue 39, Euro Journals Publishing, Inc. [Online] Available at www.eurojournals.com/finance/htm[Accessed April 28, 2013]

Amin, R., Becker, S., \& Bayes, A. (1998). NGO-promoted microcredit programs and women's empowerment in rural Bangladesh: Quantitative and qualitative evidence. Journal of Developing Areas, 32(2), 221-237.

Ahmed, A., Amin, R., St Pierre, M., \& Haq, R. (2001). Integration of an essential services package (ESP) in child and reproductive health and family planning with a micro-credit program for poor women: experience from a pilot project in rural Bangladesh. World Development, 29(9), 1611-1621.

Anyanwu, C. M. (2004). Micro finance institutions in Nigeria: Policy, Practice and Potentials being a paper presented at G24 Workshop "Constraints to Growth in Sub Saharan Africa" Pretoria, South Africa, November, 29-30, 2004.

Banerjee, A., Duflo, E., Glennerster, R., \& C. Kinnan (2009), "The miracle of microfinance?

Evidence from a randomized evaluation",

Baumann, T., (2001).Microfinance and Poverty Alleviation in South Africa, Cape Town: Bay Research and Consultancy Services. Available online at: http://talk.to/brcs

Baumann, T., (2004), Pro-poor Microcredit in South Africa. Journal of Microfinance, 7(1).

Cull, R., Demirgüç-Kunt, A., \& Morduch, J. (2007). Financial Performance and Outreach: A Global Analysis of Leading Microbanks. The World Bank.

Dunnford, C. Woller, G., \& W. Woodworth (1999), "Where to Microfinance". International Journal of Economic Development, Vol. 1, No. 29, pp. 30-64.

GHAMFIN (2006) "Microfinance Poverty Outreach and Performance Assessment: A Study of Rural Microfinance Institutions And Government Programmes In Ghana; Ghana Microfinance Institution Network (GHAMFIN) Accra, Ghana

Hume, D. \& Mosley, P. (1997) "Finance for the Poor or Poorest? Financial Innovation, Poverty and Vulnerability' in Who needs Credit? Poverty and Finance in Bangladesh" (eds) G. D. Wood and I. Sharif, University Press Limited, Dhaka, and Zed Books, UK

http://business.myjoyonline.com/pages/news/201306/108212.php

http://www.ghanaweb.com

Igbinedion, O. J. \& Igbatayo, A. S. (2004), "Micro Credit and Poverty Reduction in Sub-Saharan Africa: Challenges and Policy Framework in Nigeria". Nigeria Journal of Business Administration, Vol. 6, No. 2, pp. 15-35.

Khandker, S. R. (1998). Fighting poverty with microcredit: Experience from Bangladesh. New York: Oxford University Press.

Kushoka, I., (2013). Contribution of Microfinance Institutions to Entrepreneurship Development in Tanzania, International Journal of Business and Management Tomorrow, Vol. 3 No. 3

Ledgerwood J (1999). "Microfinance Handbook on Sustainable Banking with the Poor: An Institutional and Financial Perspective.” The World Bank: Washington. D.C.

Lariviere, S., \& Martin, F. (1998). Innovations in rural microfinance: The challenge of sustainability and outreach. Innovations in Microfinance for Rural Poor: Exchange of Knowledge and Implications for Policy. Washington, DC: IFPRI.

Meyer, R. L. \& Zeller, M. (2002), "The Triangle of Microfinance: Financial Sustainability, Outreach, and Impact”, The Johns Hopkins University Press, USA 21211-4370

Navajas. S. M., Schreiner. R. L., Meyer. C., Gonzalez-Vega \& J. Rodriguez-Meza, (2000), “ Micro credit and the Poorest of the Poor: Theory and Evidence from Bolivia," World Development, Vol. 28, No. 2, pp 333-346, Elsevier Science Ltd.

Otero, M. (1999), "Bringing Development Back into Microfinance", Journal of Microfinance Peprah, J. A., \& Muruka, G., (2010). Factors Affecting the Distribution of Microfinance Institutions in Ghana, The Journal of Business and Enterprise Development, ISSN 2026-500X

Quansah P., Amankwah E. \& Aikins E., (2012). Influence of Micro Finance and Small Loan Centre (MASOC) 
on the Development of Small Scale Enterprises in the WA Municipality. European Journal of Business and Management, 4(1)

Rahman, A. (1998). Micro-credit initiatives for equitable and sustainable development: Who pays? World Development, 27(1), 67-82.

Robinson M. S. (2001). The Microfinance Revolution: Sustainable Finance for the Poor. The World Bank, Washington, D.C.

Rogerson, C. M. (2001). Growing the SMME Manufacturing Economy of South Africa: Evidence from Gauteng Province. J. Contemp. Afr. Stud., 19(2): 267-291.

Rutherford, S., (1999). The poor and their money: an essay about financial services for poor people, Manchester, UK: Institute of Development Policy Management [Online] Available at: [http://www.microfinancegateway.org/content/article/detail/1737]

Rwigema H., \& Karungu P. (1999). SMME development in Johannesburg's Southern Metropolitan Local Council: an assessment. Dev. South. Afr., 16(1): 101-124.

Schreiner, M. (2002). "Aspects of Outreach: A Framework for Discussion of the Social Benefits of Microfinance." J. Int. Dev. 14: 591-603.

Sebstad, J. \& Cohen, M. (2003). Reducing Vulnerability: The demand for microfinance. A synthesis report. Nairobi: Micro Save-Africa.

\section{Biography}

Akwasi A. Boateng was born in Accra, Ghana and is a Lecturer at the School of Business, Cape Coast Polytechnic. He became an Associate Member of the Chartered Institute of Bankers, Ghana in 2009, having passed the Associateship Examination. He has a B.Com. degree from the University of Cape Coast, MBA from Newport International University, Wyoming, USA in 2007 and Master of Arts in Business Planning and Microfinance, University for Development Studies, Ghana in 2013. His research interest includes SME's financing, Corporate Governance, Regulation and Supervision of MFIs. He can be reached at akwasik2004@hotmail.com and by phone at +233205905219 .

Gilbert O. Boateng was born in Accra, Ghana and is a Lecturer at the School of Business, Takoradi Polytechnic. He became an Associate Member of the Chartered Institute of Bankers, Ghana in 2011, having passed the Associateship Examination. He has a B.Sc. degree in Business Administration (Banking and Finance) from the University of Ghana, Legon- Accra, Ghana in June, 2000 and a M.Sc. degree in Economics and Finance from the University of Skovde in Sweden awarded in May 2005. His research interest includes Development Finance and Economics, Monetary Economics and Central Banking. He can be reached at gillyboateng@yahoo.com and by phone at +233242777480 . 